\title{
A Comparative Study of the Legal Frameworks and Protection of Digital Content in the United Arab Emirates and Australia in Relation to the Practice of Blocking Digital Content on the Basis of Location (Geo- Blocking) and its Associated Circumvention Technologies
}

\author{
Bradley John Young* \\ Assistant Professor, College of Communication and Media, Zayed University, Abu Dhabi-144534, United Arab Emirates
}

\begin{abstract}
This paper examines the legal frameworks of both Australia and the United Arab Emirates as it relates to the World Intellectual Property Organization (WIPO) international treaty. It explores the wording of the treaty and its subsequent implementation in those jurisdictions citing both legislative and jurisprudence around the notions of Technical Protection Measures. It is through the examination of the operationalization of this term that the limited effect of this treaty and the need for more explicit definition of terminology utilized is evident. This clarification will assist in the identification of the role that law can play in terms of more defined and effective legal remedies.
\end{abstract}

\section{Publication History:}

Received: December 18, 2013

Accepted: January 04, 2014

Published: January 06, 2014

Keywords:

International Copyright Law, Media Law, Technological Protection Measures, GeoBlocking, Digital Rights Management, WIPO Copyright Treaty, Australia, United Arab Emirates

\section{Introduction}

The World Intellectual Property Organization (WIPO) Copyright Treaty is intended to work in concert with the Berne Convention for the Protection of Literary and Artistic Works (Berne Convention) [1]. The WIPO treaty was signed by both Australia (Accession: April 26, 2007) and the United Arab Emirates (UAE) (Accession: April 14, 2004) and as at 5 October 2013 there were 90 countries that had adopted it [2]. The WIPO Copyright Treaty in Article 11 makes particular reference to technological developments and the obligations of contracting parties.

"Contracting Parties shall provide adequate legal protection and effective legal remedies against the circumvention of effective technological measures that are used by authors in connection with the exercise of their rights under this Treaty or the Berne Convention and that restrict acts, in respect of their works, which are not authorized by the authors concerned or permitted by law [3]."

While the almost limitless benefits of enabling technologies are not in dispute, significant challenges, however, do indeed exist due to the nature of technology itself in that the reproduction of copyright content: is inexpensive; can take many forms and modes of delivery; is not sensitive to what is lawful or not; and infringers can be numerous and anonymous [4]. This brings into question the wording of what constitutes an "effective technological measure" as the existence of a circumvention technology by definition has the potential to render the technological measure ineffective. Indeed, as a result it is debatable as to whether it is possible to have a meaningful definition of "adequate legal protection" or the construction of an "effective legal remedy." The restriction of access to information based on geographical location (Geo-Blocking) is just one of many Technological Protection Measures (TPM) copyright holders have employed to protect their works. There are a variety of technical methods to block access to a particular website/online material, servers, and/or devices available to an Internet service provider (ISP), such as Uniform Resource Locator (URL), Internet Protocol (IP), Global Positioning System (GPS), [5] and Domain Name Server (DNS) look-up blocking, along with the use of particular protocols and ports [6]. These methods have experienced limited to no success as circumvention techniques have quickly been developed and exploited. Other techniques also have included over the years various Digital Rights Management (DRM) schemes usually taking the form of software encryption methods. Furthermore, the use of DRM schemes has seen their share of legal battles over a range of issues including "fair use" and the creation of monopolies. Steve Jobs (former co-founder and CEO of Apple Inc.) has stated that DRM was ineffective against piracy [7]. Apple's iTunes ${ }^{\circledR}$, for example, with its FairPlay ${ }^{\otimes}$ software technology was recently determined by a Californian appeals court not to be an illegal monopoly and that Apple did not break antitrust laws, but class actions such as this can take time and be very expensive [8].

Australia and the UAE have evolved very different legal traditions: viz. the UAE being Shari 'a law and Australia a common law country. Therefore, understanding the influences on not only the manner in which laws are produced but also their interpretation into an operating law is key. This insight is significant as it forms the foundation necessary to inform any efforts for international treaties addressing intellectual property and copyright, along with the real and meaningful operational management of circumvention technologies that are now a ubiquitous component of the Internet. The importance of this research is that it navigates areas of synergy, divergence, and illuminates points of tension that either requires reconciling and/or has a rich complexity not easily resolved.

*Corresponding Author: Dr. Bradley John Young, Assistant Professor, College of Communication and Media, Zayed University, Abu Dhabi- 144534, United Arab Emirates, Tel: +971 2 5993696; E-mail: bradley.young@zu.ac.ae

Citation: Young BJ (2014) A Comparative Study of the Legal Frameworks and Protection of Digital Content in the United Arab Emirates and Australia in Relation to the Practice of Blocking Digital Content on the Basis of Location (GeoBlocking) and its Associated Circumvention Technologies Int J Journalism Mass Comm 1: 101. doi: http://dx.doi.org/10.15344/2349-2635/2014/101

Copyright: (c) 2014 Young. This is an open-access article distributed under the terms of the Creative Commons Attribution License, which permits unrestricted use, distribution, and reproduction in any medium, provided the original author and source are credited. 
Citation: Young BJ (2014) A Comparative Study of the Legal Frameworks and Protection of Digital Content in the United Arab Emirates and Australia in Relation to the Practice of Blocking Digital Content on the Basis of Location (Geo-Blocking) and its Associated Circumvention Technologies Int J Journalism Mass Communicat 1: 101. DOI: http://dx.doi.org/10.15344/2349-2635/2014/101

\section{Literature Review}

\section{Geo-Blocking: technical methods and circumventions}

Internet filtering is a common practice in at least 40 countries whereby content often relating to politics, sexuality, culture, or religion is considered by the government in that country as inappropriate for their population [9]. This is usually achieved by filtering all Internet traffic through a proxy server (as is practice in the UAE) and should a user attempt to access a site deemed "unsuitable" they are presented with the following statement in Figure 1.

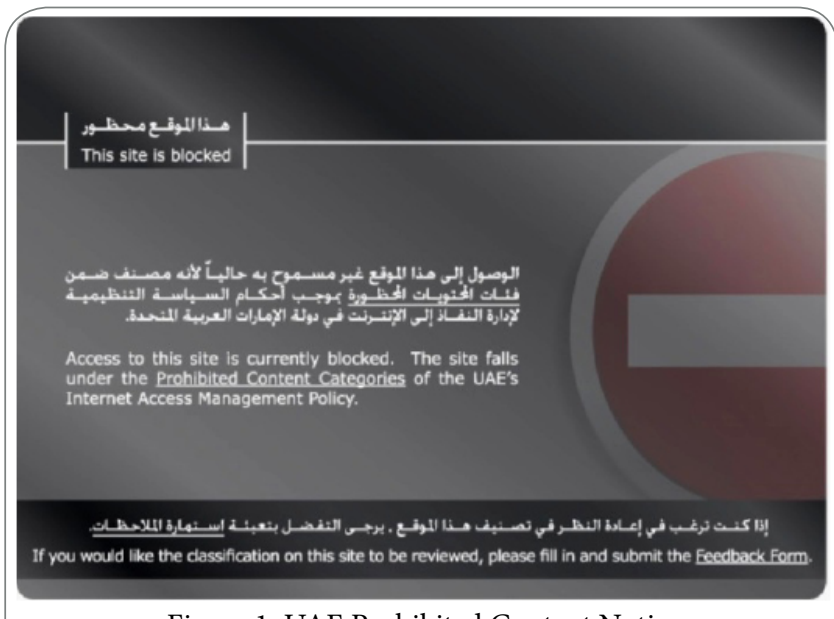

Figure 1: UAE Prohibited Content Notice

"Access to this site is currently blocked. The site falls under the Prohibited Content Categories of the UAE's Internet Access Management Policy. If you would like the classification on this site to be reviewed, please fill in and submit the Feedback Form"

In Australia's case the opposite problem exists because the content is blocked from coming to Australia by the source, for a range of reasons (often commercial in nature) that will be explored. Circumvention for both scenarios of content blocking, based on geographical position (either by the originator or the receiving location), can be accomplished by using another location to access the material on your behalf, thus giving the impression that your request originated elsewhere on the globe. The use of a proxy server in a country that is not blocked (sometimes referred to as "Tunneling") [10] or the uses of a Virtual Private Network (VPN) [11] are the most commonly used methods of circumvention. Both methods can be executed securely using a range of encryption technologies. There is, however, a performance cost associated that is particularly noticeable; for example T1 (1.544 Mbit/s) or higher links [12] in the case of a VPN. The implication of this is that there is speed and performance degradation when using either of these techniques. By comparison the UAE does not operate as a free market economy so Etisalat and Du function as a monopoly. Even with the existence of numerous "free zones" these are highly regulated and controlled. VPNs still pose a significant challenge to both the public and private sector in terms of compliance and control [13].

At present, identification of media on the network, in particular music or video files, where the work is a single object or a traditional web page can be a relatively straightforward process. Things become much more complicated when we talk about notions such as Sir.
Tim Berners-Lee's "semantic web" [14] whereby we are no longer talking many instances of varying transience, stored globally This has serious implications in terms of the future ramifications and complex challenges that are foreshadowed by the evolving design of technology that concern definition, particularly when trying to apply traditional concepts such as those found in the Copyright Act 1968

(Cth) a "work" [15].

\section{The UAE}

\section{Political structure}

Political Structure Situated in the Eastern part of the Arabian Peninsula, The United Arab Emirates (UAE), is not one country but a Federation of seven Emirates: viz. Abu Dhabi (the capital and largest Emirate), Dubai, Sharjah, Ras al Khaimah, Umm al Qaiwain, Fujairah, and Ajman. Formerly known as the Trucial States under British protection, the country gained independence in 1971 when it became the United Arab Emirates but only adopted a permanent Constitution in 1996. The Constitution of the UAE established the positions of President and Vice-President who are elected at five yearly intervals by the Supreme Council. The Supreme Council, which is comprised of the rulers of each of the seven Emirates, is the top policy-making body in the government. HH Sheik Zayed bin Sultan Al Nahyan held the position of president of the UAE from the time of Federation until his death in 2004 when, in accordance with the Constitution, his son HH Sheik Khalifa bin Zayad Al Nahyan was elected by the Supreme Council to succeed him [16].

The Supreme Council also approves and appoints members for the Council of Ministers (cabinet). Headed by the Prime Minister, the Council of Ministers is the executive authority for the Federation, initiating and implementing laws for approval by the Supreme Council [17]. In addition to the Supreme Council and the Council of Ministers is a forty-member Federal National Council (parliamentary body) drawn from each Emirate and appointed by the Prime Minister. The Federal National Council functions in a consultative capacity reporting to the Supreme Council and the President [18]. Furthermore, the Federal Judiciary, whose independence is guaranteed by the constitution, includes the Federal Supreme Court and the Courts of First Instance [19].

However, traditional government, having roots in Bedouin culture, still plays an important role in the government of the UAE operating on the principle of the people having free access to their Sheikh. The institution of the majlis through which consultation and consensus takes place [20] enables the people to raise issues with their rulers. This aspect is essential to an understanding of the political structure in the UAE. The UAE is consistent with the legal tradition of a Sharia law state, whereby the judicial process has as its core the Koran and the teachings of the prophet Mohammed (PBUH). Shari'a law literally means "path to follow" and is expressed in the "fiqh", that is, the "science" of Islamic jurisprudence expressed also beyond the Koran with various interpretation, comment and analogical reasoning (Sunna, ijma, qiyas); however, the most important aspect being that of the words of the prophet Mohammed (PBUH) himself [21]. While the UAE is considered one of the most connected countries in the Middle East [22] it has automatic filtering in place, which the primary provider, Etisalat, states that this practice enjoys popular support and is an acceptable form of censorship [23]. Etisalat and Du are the only telecommunication companies in the country and are required to comply with the policies of the 
Citation: Young BJ (2014) A Comparative Study of the Legal Frameworks and Protection of Digital Content in the United Arab Emirates and Australia in Relation to the Practice of Blocking Digital Content on the Basis of Location (Geo-Blocking) and its Associated Circumvention Technologies Int J Journalism Mass Communicat 1: 101. DOI: http://dx.doi.org/10.15344/2349-2635/2014/101

Telecommunications Regulatory Authority (TRA). Deibert found that most of the filtering pertained predominantly to those topics that were; deemed obscene, were related to gambling, drugs, cults, religious conversion, along with IT websites containing anonymizers, hacking information and circumvention tools [24]. This regulation is further evidenced by the TRA Internet Access Management Policy 2008 that stipulates clearly what is required to be blocked by ISPs as shown in Table 1.

\begin{tabular}{|l|l|}
\hline 1 & Internet Content for Bypassing Blocked Content. \\
\hline 2 & Internet Content for Learning Criminal Skills. \\
\hline 3 & $\begin{array}{l}\text { Dating Internet Content: Exemptions: Chatting services, social } \\
\text { networking and forums. }\end{array}$ \\
\hline 4 & Internet Content for Illegal drugs. \\
\hline 5 & Internet Content containing pornography and nudity. \\
\hline 6 & Gambling Internet Content. \\
\hline 7 & $\begin{array}{l}\text { Internet Content for Hacking and malicious codes: Exemptions: } \\
\text { information security. }\end{array}$ \\
\hline 8 & Internet Content that are offensive to religions. \\
\hline 9 & Phishing Internet Content. \\
\hline 10 & Internet Content that downloads Spyware. \\
\hline 11 & $\begin{array}{l}\text { Internet Content providing unlicensed Voice over Internet } \\
\text { Protocol (VoIP) service. }\end{array}$ \\
\hline 12 & Terrorism Internet Content. \\
\hline 13 & Prohibited Top Level Domain (TLD) [Israel]. \\
\hline
\end{tabular}

Table 1: UAE-Telecommunications Regulatory Authority: internet access management policy-annex 1-prohibited content categories.

Very recently Skype was unblocked for computer-to-computer communication; yet, computer to telephone (landline) is still prohibited. It is surmised the rationale for this is so that Etisalat and Du can retain not only their monopoly and control but the author believes that security is a significant part of the reason. This notion is evidenced by the threatened ban on Blackberry in 2010 because of its encryption and storage of data abroad. However, the situation was averted when Blackberry (then Research in Motion) changed this practice and complied with the TRA's security requirements. [25] The most recent legislative instrument aimed at combating digital crime was the law On Combating Cybercrimes 2012 (UAE) [26] that superseded the previous law Cyber Crimes Law 2006 (UAE) [27]. This new law apart from listing higher penalties included offences specifically intended to satisfy the UAE's obligations as a signatory to international treaties [28].

\section{Laws and Decrees}

There are a number of relevant government laws and decrees to be addressed that include the Cyber Crimes Law 2006, and the Cyber Crimes Law 2012 that repeals the 2006 law where there is any inconsistency. The latter contains new additions, including "Circumventing an IP address for the purpose of committing or concealing a crime." The chronology of legislation in the UAE that pertains to technology and intellectual property has been identified here in Table 2.

\section{Australian legislation}

It not the purpose of this paper to recount the historical record of Australia's copyright law as this has already been addressed by scholars such as Atkinson [47]. In his research, Atkinson has noted the sparse knowledge of intent with regard to legislative construction and likewise notes a void of empirical evidence [48]. He does, however, express the opinion that up to the turn of this century governments "legislated to permit far-reaching digital rights management practices, restrictive copy protection, and technical protection measures [49]." The illegal downloading of copyright material amounts to misappropriation and unjust enrichment that equates to the conversion of value [50]. What is argued in this paper is that a trend has been emerging in the Australian copyright landscape to seek more clarification and exemptions in order to address important social issues and freedoms. This has already begun to have an effect and is an attempt at moving away from applying imprecise, catch-all phrases that can have the net effect of being narrow in view and restrictive in practice.

\begin{tabular}{||l|l|}
\hline Year & Title \\
\hline 1993 & $\begin{array}{l}\text { Copyright and Related Rights (Neighboring Rights), IP } \\
\text { Regulatory Body, Traditional Cultural Expressions, Utility } \\
\text { Models [29]. }\end{array}$ \\
\hline 2000 & $\begin{array}{l}\text { Dubai Technology, Electronic Commerce \& Media Free } \\
\text { Zone Law [30]. }\end{array}$ \\
\hline 2002 & Concerning Copyrights and Neighboring Rights [31]. \\
\hline 2002 & $\begin{array}{l}\text { Concerning the Formation and Protection of the } \\
\text { Telecommunication Network for Dubai Internet City [32]. }\end{array}$ \\
\hline 2002 & Electronic Transactions and Commerce Law [33]. \\
\hline 2002 & On Trademarks [34]. \\
\hline 2003 & $\begin{array}{l}\text { Regarding the Organization of the Telecommunications } \\
\text { Sector [35]. }\end{array}$ \\
\hline 2004 & $\begin{array}{l}\text { Amending the Dubai Technology, Electronic Commerce and } \\
\text { Media Free Zone [36]. }\end{array}$ \\
\hline 2004 & $\begin{array}{l}\text { On Collective Management of Copyright and Related Rights } \\
\text { [37]. }\end{array}$ \\
\hline 2004 & $\begin{array}{l}\text { On Compulsory Licensing of Copies or Translations of } \\
\text { Works [38]. }\end{array}$ \\
\hline 2006 & Concerning Consumer Protection [39]. \\
\hline 2006 & Cybercrime Law [40]. \\
\hline 2006 & $\begin{array}{l}\text { Pertaining to the Industrial Regulation and Protection of } \\
\text { Patents, Industrial Drawings, and Designs [41]. }\end{array}$ \\
\hline 2007 & Data Protection [42]. \\
\hline 2008 & $\begin{array}{l}\text { Regarding the issuance of Certification Service Provider } \\
\text { Regulations [43]. }\end{array}$ \\
\hline 2012 & $\begin{array}{l}\text { On The Establishment Of The National Electronic Security } \\
\text { Authority [44]. }\end{array}$ \\
\hline 2012 & On The Regulation Of Competition [45]. \\
\hline 2012 & On Combating Cybercrimes [46]. \\
\hline
\end{tabular}

Table 2: List of UAE Laws and Decrees relevant to Technology and Intellectual Property. 
Citation: Young BJ (2014) A Comparative Study of the Legal Frameworks and Protection of Digital Content in the United Arab Emirates and Australia in Relation to the Practice of Blocking Digital Content on the Basis of Location (Geo-Blocking) and its Associated Circumvention Technologies Int J Journalism Mass Communicat 1: 101. DOI: http://dx.doi.org/10.15344/2349-2635/2014/101

Furthermore, to illustrate this shift in Australia we see that the Copyright Act 1968 (Cth) in particular, section 10(1) was identified for review by the Standing Committee on Infrastructure and Communications, Parliament of the Commonwealth of Australia and is evidenced by their report: At what cost? IT pricing and the Australia tax (2013) [51]. The Committee made 10 recommendations including the proposal that the Australian Government amend the Copyright Act's section 10(1) anti-circumvention provision. This report while acknowledging in some cases that Geo-Blocking (blocking of websites based on location) is a "necessary business practice [52]" it was overwhelmingly negative towards its usage stating that it limited consumer's ability (access and choice) in online trade and commerce (the global marketplace). The Committee found that as a regular practice Australia was being charged more for a comparable item than in other jurisdictions. Recommendation 5 was to amend aspects of the Copyright Act's anti-circumvention provisions so as to clarify and legitimise a consumer's right to "circumvent technological protection measures that control geographic market segmentation [53]." Another recommendation was to amend the Competition and Consumer Act 2010 (Cth) [54] to void contracts and terms of service that perpetuate/ enforce Geo-Blocking. If adopted, a further recommendation would repeal section 51(3) of the Competition and Consumer Act 2001 (Cth) to permit the operation of the Australian Competition and Consumer Commission (ACCC) in these markets [55].

Furthermore, the committee noted in the submissions by the Australian Communications Consumer Action Network (Submission 74) and Faye Galbraith (Submission 78) that Information Technologies designed for people with a disability are not comparably priced and often cost significantly more [56]. When examining this issue and its relationship to Geo-Blocking an important and in some regards similar technique is Geocoding. Geocoding as the name implies geographically codes the content/information providing the opportunity to selectively present it: and can also be used to completely block; provide a completely different language; or price inter alia, and in many ways that is not dissimilar to region coding of a DVD. Based on this logic it could be argued that it is more an access control measure (ACM) that does not fall under the definition of a TPM [57]. So therefore, it becomes increasingly apparent that the limited access and price differentials related to products and services provided in an ever increasingly interconnected society creates an online inter-dependency that becomes a "significant contributor to the social isolation and economic marginalisation of Australians, including those who are living with disability [58]." It does not take much more to extrapolate from this the questions that it raises of ethical and moral responsibility. The Committee, in Recommendation 4 , also called for a review and broadening of the parallel importation restrictions found in the Copyright Act and the importation defence in the Trade Marks Act 1995 (Cth) [59]. Generally, the exploration of other measures was encouraged but the banning of Geo-Blocking was considered an extreme measure and one only available as a "last resort" in Recommendation 9 [60].

Price variations were also found to exist between shipping costs and online digital purchase costs in computer games between Australia and the United Kingdom (UK) [61]. In Recommendation 7 the creation of a "right of resale" and further articulation of the fair use provisions to increase competition, particularly with mobile markets and restrict vendors abilities to "lock digital content into a particular ecosystem" [62] drew considerable comment. Moreover, justification for the practice of varying prices according to geographical location made by Adobe and Microsoft inter alia were the result of (they claimed) digital content pricing differentials experienced in the marketplace. The interpretation of fair use is not uniform, homogenous, or even remotely cohesive in common law countries. For example, the definition of "technical measures" (TPM) in UK legislation is expressed in such a broad manner as to be inclusive of almost any mechanism [63]. The UK's Digital Economy Act 2010 provides for a blocking injunction under section 17 that is not specific as to the type of technology to be used or the process involved. More specifically, this section makes provisions about injunctions that provide a legislative mechanism to authorise the practice of GeoBlocking [64]. This legislation authorises the regulations to make provisions that are inclusive of VPN's whereby one location can be considered as facilitating access to another location [65]. Such legislation is extremely broad sweeping and could also be described as a catchall in nature.

Before the parliament this year in Australia is a Bill sponsored by Senator Scott Ludlam, the Copyright Legislation Amendment (Fair Go for Fair Use) Bill 2013 (Cth). The summary of this Bill states that it:

"Amends the Copyright Act 1968 to: provide that digital locks or technical protection measures that restrict accessibility for the visually impaired and disabled are removed; provide legal protection to universities, libraries, schools, cultural institutions, content service providers and internet service providers from being sued when other persons have accessed certain online content; remove geocodes from the use of overseas content; and provide for a fair use exception [66]"

It must be noted that concurrently the Australian Law Reform Commission's (ALRC) Review of Copyright in the Digital Economy is presently considering proposing among other things the introduction of a fair use regime (report due to be released 30 November 2013) [67]. The issue paper on Copyright and the Digital Economy from the ALRC68 contains a number of questions regarding TPMs and exceptions, particularly in reference to the Copyright Act 19 [68] (Cth) s 47(c) for making backup copies and s 111 for time shifting [69]. Trying to make sense, however, of the breadth and scope of "legal protection" one scholar suggested that it "might" be understood as: general access control measures; limited access control measures; use control measures; and antidevice measures [70]. currently the submissions, publically available and listed from organisations number 222 with individual submissions totalling 341. Such figures indicate the degree of importance and diverse interest that is making technological protection measures and intellectual property a very important topic to many Australians resulting in as Flew, Suzor, and Liu describe "copyrights" [71].

\section{Leading cases}

Case law has shown that there has been a shift and a willingness to apply a more resilient approach that makes the effort to establish clearer operating principles as opposed to catch-all legislative phrases and this practice, when considering Common law in Australia and the Sharia law UAE, has generated greatly divergent judicial reasoning.

The Federal Court in February 2010 handed down three significant copyright cases: Roadshow Films $v$ iiNet; [72] Larrikin Music Publishing v EMI Songs Australia; Telstra Corporation $v$ Phone Directories Company [74]. In Roadshow Films $v$ iiNet the High Court confirmed that in Australia an Internet Service Provider (ISP) under the Copyright Act is not responsible for the infringement of third 
Citation: Young BJ (2014) A Comparative Study of the Legal Frameworks and Protection of Digital Content in the United Arab Emirates and Australia in Relation to the Practice of Blocking Digital Content on the Basis of Location (Geo-Blocking) and its Associated Circumvention Technologies Int J Journalism Mass Communicat 1: 101. DOI: http://dx.doi.org/10.15344/2349-2635/2014/101

parties (i.e. their subscribers) using their infrastructure. Section 112E inserted into the Copyright Act by the Digital Agenda Act [75] describes that provision (distinguishing ISPs) does not equate to authorisation. Furthermore, Paltiel claims that the landmark "Moorhouse case" [76] is partially incorporated into the amendments of the Digital Agenda Act [77]. The High Court in 2012 unanimously dismissed an appeal by 34 Australian and American films and television companies (including Disney, Warner Bros. and the Seven Network). [78] However, this decision clearly placed the onus and burden for the monitoring and enforcement of matters on the copyright holder. Larrikin Music Publishing v EMI Songs Australia was also interesting due to the quantitative test of $50 \%$ reproduction that becomes of further interest if translated into the digital medium. In Telstra Corporation v Phone Directories Company the difficulties of treatment for owners of a compiled work were explored in terms of attribution and authorship that again navigates difficult space in the digital arena. Singtel Optus Pty Ltd v National Rugby League Investments Pty Ltd [79] is another important case whereby Optus was found to infringe copyright with its "TV Now" service and had relied on the exemption s 111 of the Copyright Act 1968 (Cth) [80]. Curiously it was also noted that the service was not dissimilar to such a degree to that of a video or DVD recorder [81]. A "time-shifted" broadcast is used to describe the practice of making a recording for personal use so as to view or listen at a more convenient time [82]. There was a question, however, that remained unclear which was the matter of whether the copies stored on Optus' Network Attached Storage (NAS) servers were in fact a copyright infringement. Also recently, cases that invoked the Court Suppression and Non-Publication Orders Act 2010 (NSW) [83] were Fairfax Digital Australia and New Zealand Pty Ltd and Others $v$ Ibrahim and Others, [84] and Rinehart $v$ Welker [85]. This year it was made explicit in Phonographic Performance Co of Australia Ltd $v$ Commercial Radio Australia Ltd [86] that a radio station required online streaming to be stipulated as part of their license and if this was not the case they then were confined to traditional methods of broadcasting in their geographical location.

\section{Legal Frameworks and Technological Protection of Digital Content}

Gasser's (2006) developed a best practice model of Legal Frameworks and Technological Protection of Digital Content [87]. This analysis forms the foundation for discussion and comparison between the United Arab Emirates (UAE) and Australian contexts as it applies to Geo-Blocking and associated circumvention technology laws.

The Gasser framework is in 3 parts: legal frameworks; elements of anti-circumvention legislation; and core areas of concern. This model describes legal frameworks as the third layer of protection for digital works against the circumvention of TPMs. Anticircumvention legislation includes 3 elements: subject matter and scope; exemption interface; sanctions and remedies (jurisdictional differences or "Design Choices") [88]. Furthermore, the areas of concern focus on 3 elements also, being: autonomy and participation; issues of innovation; and (negative) impacts on competition [89].

According to Gasser there has been some question as to whether access control technologies fall within the scope of the WIPO Internet Treaties [90]. This is because of the nature of the technology and the fact that accessing the work requires the duplication (however transient) in either RAM or physical storage (e.g. cache) as per Singtel
Optus v National Rugby League Investments [91]. Accessing the work in digital form is consistent with the Berne Convention in that this temporal and transient storage is a reproduction right [92].

Section 103 of the Digital Millennium Copyright Act (DMCA) in the United States adds a new chapter 12 to Title 17 of the U.S. Code and section 1201. This implements the obligation of "adequate" and "effective" protection against circumvention of TPMs used and is divided into two categories; one being access and the other copying. Arguably, one of the most famous cases in that country being that of Dmitry Sklyarov who demonstrated at a conference, software that circumvented Adobe's eBook PDF security [93].

The six exceptions found in the DMCA are: Nonprofits library (s 1201(d)); Reverse engineering (s 1201(f)); Encryption research (s 1201(g)); Protection of minors (s 1201(h)); Personal privacy (s 1201(i)); Security testing (s 1201(j)) [94]. Gasser in his study of the United States believes that treaties such as AUSTFA [95] establish a high level of protection beyond the obligations of WIPO: and that WIPO Performances and Phonograms Treaty (WPPT) [96] (Article 18 of the WPPT contains nearly identical language to WIPO Article 11). In addition, AUSTFA requires further amendments to the Australasian Copyright Act beyond that already made by the Australian Copyright Amendment (Digital Agenda) Act 2000 (Cth) [97]. Indeed, The Australian Copyright Amendment (Digital Agenda) Act 2000 (Cth) inserts the word 'effective' into the definition of circumvention device and circumvention service [98]. This notwithstanding, Gasser citing a Standing Committee report [99] identified that AUSTFA differed from the Copyright Act in: definition of a TPM; scope of exceptions; liability rules; and adequate legal protection [100]. Exceptions have been adopted internationally and there is a considerable degree of variance and inclusivity under discussion [101]. In the Fair Go for Fair Use Bill 2013 (Cth) we see firsthand the tension and a clear desire manifested in order to make certain exemptions more explicit.

\section{Research Design and Methodology}

\section{Design and document analysis}

\section{Grounded theory}

The purpose of grounded theory as a type of research method is to inductively develop theory for the source data [102]. It is "the discovery of theory from data systematically obtained from social research [103]." While initially developed by Glaser and Strauss in 1967 it has been noted by Connelly in 2013 that there are now two versions: Glaser's, and Strauss and Corbin because over the years they disagreed on the nature of the method [104]. However, it is not within the scope of this research to discuss the differences between types of grounded theory methodology, apart from acknowledging the two versions.

The basic idea underlying the grounded theory approach is the examination of textual data in order to perceive variables and determine how they interrelate. A significant aspect of this method is that the researcher does not formulate a preconceived hypothesis but allows the relationship between concepts to generate an original theory from the data. Charmaz states that, "grounded theory methods consist of systematic, yet flexible guidelines for collecting and analyzing qualitative data to construct theories 'grounded' in the data themselves [105]". 
Citation: Young BJ (2014) A Comparative Study of the Legal Frameworks and Protection of Digital Content in the United Arab Emirates and Australia in Relation to the Practice of Blocking Digital Content on the Basis of Location (Geo-Blocking) and its Associated Circumvention Technologies Int J Journalism Mass Communicat 1: 101. DOI: http://dx.doi.org/10.15344/2349-2635/2014/101

Grounded Theory in this instance has also been applied in a manner consistent with Bloom's taxonomy whereby the researcher requires a functional knowledge of the field to be able to understand the phenomenon being examined, make sense of it, and undertake coding and analysis of the texts [106]. A fundamental component of grounded theory is concurrent data collection and analysis [107] and is very compatible with the view of legal doctrine as a hermeneutic discipline [108]. The analysis of data is often referred to as 'coding' of which three types are used; open or substantive, axial, and selective coding. The first step in coding called open coding is used at the beginning of the research to identify concepts that some of the facts represent. Axial coding consists of identifying relationships. Strauss and Corbin defined axial coding in 1990 as "a set of procedures whereby data are put back together in new ways after open coding, by making connections between categories [109]". Selective coding, the final stage of data analysis, is the process of identifying a core concept and relating all other categories to that conceptual point. Strauss and Corbin define selective coding as "the process of selecting the central or core category, systematically relating it to other categories, validating those relationships, and filling in categories that need further refinement and development [110]."

\section{Document analysis}

The research method of document analysis is an important tool used extensively in qualitative research and researchers analyse virtually anything that supports the research question. Guba and Lincoln state that "documents and records, observations, the professional literature, inputs from other circles' construction, and the evaluator's etic construction... are legitimate sources for information bearing on existing construction [111]." Furthermore, compared to other research methods such as observations, interviews and questionnaires, the technique of document analysis is significant in the fact that it analyses "written documents" and thus avoids researcher influence that other techniques have on the data [112]. Moreover documents are resources, which can more easily be revisited.

\section{Data sources}

In addition to conducting searches throughout the appropriate USQ library databases and government information available online, materials held at or accessible through the University of Sydney, Zayed University, and United Arab Emirates University were utilized along with materials used as part of teaching in the Master of Science (M.S.) in Information Technology Specialization in Cyber Security at Zayed University plus the relevant technical literature to explain Geo-Blocking and emerging obfuscation technologies. Requests were made for access to documents from the following sources: Abu Dhabi Judicial Department (ADJD); UAE Federal Court judgements; and Local legal practices (e.g. Al Tamimi). Generally, news services provided a valuable starting point in terms of identifying important issues and other primary sources for exploration. News services include but are not limited to: NewsCorp Australia, Gulf News, Emirates News Agency, Khaleej Times. UAE Specific-Al Tamimi Law Update (UAE law review). Key treaties (e.g. Budapest Convention on Cybercrime, [113] and the WIPO Internet treaties [114]) and issues associated with their continued compliance, relevance, and sustainability in a changing landscape. The principle challenge for this research concerned the UAE and gaining sufficient access. While the government proclaims transparency there are still significant in terms of access to current and accurate information. The federal laws and decrees are published by official government sources; however, there is limited supporting documentation on their interpretation and information of their enforcement that is freely available. Limited documentation held in the University's Emirates Collections and the Judiciary School of the United Arab Emirates University collections was employed for the purpose of this research.

\section{Method}

This study provides a methodological contribution through the workflow and analysis schema used as the basis for comparison in $\mathrm{NVIVO}^{\mathrm{TM}}$. Due to the short time that was available to undertake this research, the design/methodology was limited in scope to encompass an examination of the available literature and undertake initial document analysis of official and published sources only i.e. no interviews were conducted. The qualitative procedures involved in this methodology began with the primary sources being gathered along with their relevant sections and entered into an Endnote ${ }^{\mathrm{TM}}$ (Version X6) database. This was done not only as a reference manager to better facilitate the writing of the final report but also as an important step in the research workflow to prepare the material for porting to NVIVO ${ }^{\mathrm{TM}}$ (Version 10) software.

Once the data had been collected and prepared in NVIVO $^{\mathrm{TM}}$ the process of coding could then be undertaken. However, it must be noted that this process was non linear and of a hermeneutic design that informed both the exploration and process undertaken throughout, equally including the literature review as well as the analysis. This type of approach also allows for a much earlier engagement and facilitates a faster retrieval of topic material for the writing of a literature review [115].

\section{Discussion}

A lack of synergy between signatory parties to the WIPO Copyright Treaty coupled with the evolving nature of technology confirms the traditional difficulty for legislators and the judiciary when attempting to address issues related to technology and copyright. This challenge has dated back to the Guttenberg printing press and is evidenced in Samuel Clemen's (Mark Twain) address to parliament on copyright [116].

\section{Technological protection measures (TPMs)}

Member states to the WIPO treaty are under no obligation to outlaw circumvention of TPMs and that "acts permitted by law" are considered an exception (and also a limitation) [117]. Therefore, while there is no consensus or meaningful/workable definition at present there is nevertheless clear international political and judicial pressure to continue efforts to clarify these terms, or determine whether other more useful definitions should be adopted. Some of the key problems with the legal and legislative third layer of protection against the cultural backdrop of a Western society (such as Australia) have been cited by scholars [118] (e.g. empirical evidence being unclear) and that the legislative trend is to: "promote digital lock-up; inhibit fair use, fair dealing, and other copyright privileges; limit access to public domain works; prevent legitimate research, including reverse engineering and encryption research; generally inhibit the free flow of information and freedom of expression; be misused to prevent legitimate competition; disadvantage disabled users; decrease consumer autonomy; and 
Citation: Young BJ (2014) A Comparative Study of the Legal Frameworks and Protection of Digital Content in the United Arab Emirates and Australia in Relation to the Practice of Blocking Digital Content on the Basis of Location (Geo-Blocking) and its Associated Circumvention Technologies Int J Journalism Mass Communicat 1: 101. DOI: http://dx.doi.org/10.15344/2349-2635/2014/101

Page 7 of 11

Gasser is of the opinion that anti circumvention legislation has modified and changed a balance that was embodied in respective national copyright laws in terms of rights and limitations [120]. In efforts to address this we see the emergence of Bills such as the Copyright Legislation Amendment (Fair Go for Fair Use) Bill 2013 (Cth). There is little ongoing debate regarding the evidence on the TPM legislation's effects on piracy and its being an enabling factor to support certain business models as well as the unintended consequences of the third layer protection and core societal values [121]. It is of interest to compare various sanctions and remedies and whether they adhere to a level of proportionality or equivalence in terms of criminal and civil liability. Difficulty arises in subscribing to Gasser's simplification of the terminology problem in his solution for "effective." The concept of an "effective" TPM he specifies as:

1. It functions properly;

2. It can only be disabled intentionally and with considerable difficulty; and

3. No easier means exist to achieve the effect the measure attempts to prevent [122].

What does considerable difficulty mean? What might be considerable for a nontechnical individual might be a simple procedure for a 10 year old today. It could be argued that this has just replaced one word that lacks clarity of definition with another that is just another nebulous term. Judgements have attempted to provide some clarification and definition when addressing new concepts such as TPMs and associated methods. For example, region coding in Stevens v Sony [123] was found not to "inhibit" copyright infringement. It therefore begs the question as to whether the same could be said for Geocoding. It was found that in accordance with s 10(1) of the Copyright Act, Sony's protection device was a TPM. The use of the Playstatio ${ }^{\mathrm{TM}}$ did not involve the reproduction in material form substantially in part or as a whole. This directly relates to the question of "effective" TPM and as it can be easily circumvented it is therefore of another class that would then by definition not fall under a category classified for legal protection in Australia. By examination of the legislations it is apparent that under the WIPO treaty the copying process and ACMs are indeed encompassed and considered a part of and under the umbrella of a TPM.

As can be seen in table 3 an examination of the submissions provides an overview of the range and balance of opinions expressed. The IGEA submission No. 14 [124] represents key players in the Game Development industry. Those of particular note Blizzard, Disney, Electronic Arts, Sony, Ubisoft, and Warner, not surprisingly, clearly do not support the Bill. In their submission they outline but do not define the functions of TPMs and assert that this matter is already being examined by the Attorney-General's Department as part of the Australia-United States Free Trade Agreement (AUSTFA) [125] and then, should exceptions be warranted, these can be accommodated through modification of section 249(4) of the Copyright Act 1968 (Cth) [126]. Also specifically mentioned was geocoding whereby they expressed that they are satisfied with the existing arrangements and assert that it does not require legislative interference [127]. The Australian Recording Industry Association (ARIA) submission No. 15 [128] believe the bill inappropriate and support the separate submissions Nos. 11,12, and 27 along with drawing the Committee's attention to their submission to the ALRC [129] on the matter. One of the challenges that are not explicit in the Australian legislation at present is the distinction between an ACM and copy control within this process. However, the anti circumvention provisions have been

\begin{tabular}{|c|c|c|c|c|c|c|c|}
\hline \multirow[t]{2}{*}{ No. } & \multirow[t]{2}{*}{ Submitter } & \multicolumn{3}{|c|}{ Support for the Bill } & \multicolumn{3}{|c|}{ Addressed } \\
\hline & & Yes & No & Unclear & TPM & GeoBlock & GeoCode \\
\hline 1 & Home Loan Experts & & & $\checkmark$ & & & \\
\hline 2 & $\begin{array}{l}\text { Ms Judith Rodriguez } \\
\text { AM }\end{array}$ & & $\checkmark$ & & & & \\
\hline 3 & $\begin{array}{l}\text { Australian Institute } \\
\text { of Architects }\end{array}$ & & $\checkmark$ & & & & \\
\hline 4 & $\begin{array}{l}\text { Australian Film and } \\
\text { TV Bodies }\end{array}$ & & $\checkmark$ & & $\checkmark$ & $\checkmark$ & $\checkmark$ \\
\hline 5 & $\begin{array}{l}\text { Australian Directors } \\
\text { Guild }\end{array}$ & & $\checkmark$ & & & & \\
\hline 6 & Screenrights & & $\checkmark$ & & & & \\
\hline 7 & $\begin{array}{l}\text { BSA The Software } \\
\text { Alliance }\end{array}$ & & $\checkmark$ & & $\checkmark$ & & \\
\hline 8 & $\begin{array}{l}\text { Stuart Alexander } \\
\text { and Co Pty Ltd }\end{array}$ & & & $\checkmark$ & & & \\
\hline 9 & $\begin{array}{l}\text { Australian } \\
\text { Communications } \\
\text { Consumer }\end{array}$ & $\checkmark$ & & & & $\checkmark$ & $\checkmark$ \\
\hline 10 & $\begin{array}{l}\text { Australian Content } \\
\text { Industry Group }\end{array}$ & & $\checkmark$ & & & & \\
\hline 11 & $\begin{array}{l}\text { Australian Content } \\
\text { Industry Group }\end{array}$ & & $\checkmark$ & & $\checkmark$ & & \\
\hline 12 & Unavailable & & & & & & \\
\hline 13 & $\begin{array}{l}\text { Joint Media } \\
\text { Organisations }\end{array}$ & & $\checkmark$ & & & & \\
\hline 14 & $\begin{array}{l}\text { Interactive Games } \\
\text { and Entertainment }\end{array}$ & & $\checkmark$ & & $\checkmark$ & & $\checkmark$ \\
\hline 15 & $\begin{array}{l}\text { Australian } \\
\text { Recording Industry } \\
\text { (ARIA) }\end{array}$ & & $\checkmark$ & & $\checkmark$ & & \\
\hline 16 & Foxtel & & $\checkmark$ & & & & \\
\hline 17 & Mr John Geremin & & & $\checkmark$ & & & \\
\hline 18 & $\begin{array}{l}\text { Australasian Music } \\
\text { Publishers }\end{array}$ & & & $\checkmark$ & & & \\
\hline 19 & $\begin{array}{l}\text { Australian Society of } \\
\text { authors }\end{array}$ & & $\checkmark$ & & & & \\
\hline 20 & SBS Corporation & & $\checkmark$ & & & & \\
\hline 21 & Free TV Australia & & $\checkmark$ & & & & \\
\hline 22 & $\begin{array}{l}\text { Copyright Agency/ } \\
\text { Viscopy }\end{array}$ & & $\checkmark$ & & & & \\
\hline 23 & Ms Nell C Rundle & $\checkmark$ & & & $\checkmark$ & & \\
\hline 24 & $\begin{array}{l}\text { Australian Digital } \\
\text { Alliance and } \\
\text { Libraries }\end{array}$ & $\checkmark$ & & & $\checkmark$ & & \\
\hline 25 & $\begin{array}{l}\text { Arts Law Centre of } \\
\text { Australia }\end{array}$ & & & $\checkmark$ & $\checkmark$ & & $\checkmark$ \\
\hline 26 & APRA/AMCOS & & & $\checkmark$ & & & \\
\hline 27 & $\begin{array}{l}\text { Australian } \\
\text { Copyright Council }\end{array}$ & & $\checkmark$ & & $\checkmark$ & & \\
\hline 28 & $\begin{array}{l}\text { National Copyright } \\
\text { Unit (Education) }\end{array}$ & & & $\checkmark$ & $\checkmark$ & & $\checkmark$ \\
\hline \multirow[t]{2}{*}{29} & $\begin{array}{l}\text { Universities } \\
\text { Australia }\end{array}$ & $\checkmark$ & & & & & \\
\hline & Total $(\mathrm{n}=29)$ & 4 & 17 & 7 & 10 & 5 & 5 \\
\hline
\end{tabular}

Table 3: Summary of Submissions made to the Senate Committee for the Copyright Legislation Amendment (Fair Go For Fair Use) Bill 2013. 
Citation: Young BJ (2014) A Comparative Study of the Legal Frameworks and Protection of Digital Content in the United Arab Emirates and Australia in Relation to the Practice of Blocking Digital Content on the Basis of Location (Geo-Blocking) and its Associated Circumvention Technologies Int J Journalism Mass Communicat 1: 101. DOI: http://dx.doi.org/10.15344/2349-2635/2014/101

Page 8 of 11

used by a wide range of manufacturers (e.g. makers of toner cartridges, game consoles, and various DRMs in the music industry) in order to maintain market dominance against competition by preventing interoperability [130]. Legislating to embody treaties whose language is imprecise, that can be interpreted either very broadly or narrowly, and when expressed ambiguously, its ability to maintain currency with evolving technologies is limited. Therefore, it is of course a balance between the breadths of definition versus accuracy of interpretation. To illustrate this, Australia ratified the Budapest Convention on Cybercrime 2001[131] in 2012 with it entering into force on 1 March 2013; however, scholars have expressed concerns over its currency and relevance in this era of obfuscation technologies [132]. Furthermore, evidence given by both the Attorney-General's Department as well as the Department of Foreign Affairs and Trade have gone to the extent of declassifying Geo-Blocking as a technical protection method and therefore, not something requiring government protection via legislation (e.g. Copyright Act) [133]. One line of reasoning evidenced is going even further to classify Geo-Blocking as an anticompetitive practice [134]. While concerns exist over the relationship between TPMs and the research practices of institutions of higher education in Australia the UAE did for a period provide unfiltered access bypassing ACMs (i.e. did not go through the proxy servers for the country). Due to changes in the country's Higher Education landscape Government funded Universities as of 2013 now come under direct UAE Government control, having to adopt standardised rules and procedures similar to all government departments. This has meant the removal of unfiltered Internet access, which impacts to a degree research practices in the areas of cyber security and ethical hacking research. Moreover, the ability for exceptions to be made in the UAE does not parallel processes such as those in Australia where there is the opportunity to debate exceptions from ACMs and TCMs for libraries and other legitimate "fair use" purposes. Suzor identifies that the enforcement of intellectual property rights "poses one of the greatest current threats to the privacy of individuals online" and cites specifically Digital Rights Management Techniques i.e. TPMs as the mechanism by which this will be achieved [135].

\section{The Geo-independent Cloud}

The private as well as the public sector in an effort to stem the rising IT costs in terms of human capital, hardware/software, maintenance, infrastructure and capacity, are increasingly turning to cloud services as a cost effective mechanism. While a detailed analysis of cloud computing benefits and risks is not the focus, one key feature of this global trend is that the nature of a cloud service means that the geo location of the data could theoretically be anywhere within reach of the Internet. This immediately raises a jurisdictional question of ownership and the applicability of various laws, treaties, and agreements governing the treatment of the data. In Australia the Privacy Amendment (Enhancing Privacy Protection) Act 2012 (Cth) is intended to provide regulatory control on the crossborder disclosure of personal information [136]. This includes the outsourcing to foreign, service providers and in particular this would also encompass, more particularly, cloud based service providers. There is now an expectation that "reasonable effort" to ensure that the service provider complies with Australia's privacy laws and could be held strictly liable for non-compliance [137]. It further requires whether and where (which countries) personal information will be disclosed overseas.

In response to security and potential Geo-Blocking issues coupled with an increased reliance in the business world on cloud services, where the data is stored in another country sometimes completely unknown to the user of the service, has resulted in some significant policy statements in the UAE. For example: All medical records must be held on servers in the country in line with the prohibition on disclosing, as per The Penal Code, [138] a person's "secrets" [139] without consent [140]. The disclosure of state secrets prescribes the death penalty or life [141]. Government information is also required to be on servers in the country and this edict poses challenges for the university to comply as many institutional systems have over the years moved to cloud based solutions. In stark contrast, in Australia we could very well be witnessing the end of the practice of Geo-Blocking and Geocoding [142]. Lohman goes as far as to say that Geo-Blocking in Australia is to be dismantled [143]. As has been demonstrated by these two contrasting examples, the discretion countries have when they construct legislative and judicial mechanisms when a signatory to international treaties such as WIPO are so broad as to render Article 11 meaningless in any purposive sense without some further international agreements as to definitions.

\section{Conclusion}

Martin Luther King, Jr's Letter from a Birmingham Jail stated "Sometimes a law is just on its face and unjust in its application" [144] He was replying to the charge that his actions (the breaking of racist laws he considered immoral) were illegal by pointing out that legality and justice were not always compatible. Further difficulties arise when those operating on a different level of moral development see no incompatibility [145]. This research has clearly demonstrated that there exists a wide disparity between the interpretation and the resultant legislative and regulatory implementation of the terms of the World Intellectual Property Organization (WIPO) Copyright Treaty with regard to Technological Protection Measures (TPMs). More specifically, the use of Access Control Measures (ACMs) to restrict access to information based on geographical location (Geo-Blocking) is of such a nature that it renders in particular Article 11 of the WIPO Copyright Treaty ineffectual. It is therefore virtually meaningless in terms of any consistent, comparable, and/or compatible application between signatory parties without further clarification and agreement on the meaning in particular of effective technological measures; effective legal remedies; and ultimately adequate legal protection. While Gasser highlighted in his study of the United States and the European Union the range of interpretations that countries have adopted when implementing the "effectiveness" criterion he applied his own interpretation of intent so as to manifest a degree of compatibility [146]. This study clearly shows, however, that this intent cannot legitimately be implied due to the contrast and variability of implementation seen here between Australia's interpretation of the treaty in what could be considered an increasingly narrow sense and the UAE taking a broader, more inclusive catch-all strategy. A compounding layer further manifest when attempting to reconcile at a simple level the definition of what "access" to the Internet means as a starting point. On this point alone there is incompatibility. This being the case, then any definitions such as TPMs that are more complex would appear to be particularly challenging. Therefore, in conclusion, this comparative study of the legal frameworks and protection of digital content in the UAE and Australia in relation to the practice of GeoBlocking and its associated circumvention technologies contributes to the body of evidence showing that the WIPO Copyright Treaty Article 11 is fundamentally flawed. Moreover, it lacks meaningful definition, 
Citation: Young BJ (2014) A Comparative Study of the Legal Frameworks and Protection of Digital Content in the United Arab Emirates and Australia in Relation to the Practice of Blocking Digital Content on the Basis of Location (Geo-Blocking) and its Associated Circumvention Technologies Int J Journalism Mass Communicat 1: 101. DOI : http://dx.doi.org/10.15344/2349-2635/2014/101

requires further consideration, and more specifically clarification to be operatively and legally functional.

"Only one thing is impossible for God: to find any sense in any copyright law on the planet [147]."

Mark Twain

\section{References}

1. Berne Convention for the Protection of Literary and Artistic Works (Berne Convention) opened for signature 9 September 1886, WO001EN (entered into force 5 December 1887) 2. WIPO, Treaties and Contracting Parties: WIPO Copyright Treaty (WCT) (2013)
WIPO.

3. Berne Convention for the Protection of Literary and Artistic Works (Berne Convention), opened for signature 9 September 1886, WO001EN (entered into force 5 December 1887), art 11.

4. Internet Society (2011) Perspectives on Policy Responses to Online Copyright Infringement: An Evolving Policy Landscape.

5. Reynolds GW (2012) Ethics in Information Technology, (4th edition) Cengage Learning, United State of America, 45p.

6. Internet Society Copyright Working Group.

7. Baase S (2012) A Gift of Fire: Social, Legal, and Ethical Issues for Computing and the Internet (4th edition), Pearson Education, 233p.

8. Somers v. Apple, Inc., --- F.3d ----, 2013 WL 4712731 (9th Cir, 2013); Tim Hull, 'Apple Clears Suit Over ITunes Song Exclusivity', Courthouse News Service (Pasadena), 3rd September 2013.

9. Palfrey J, Zittrain J, Deibert R, Rohozinski R (2008) Access Denied: The Practice and Policy of Global Internet Filtering, MIT Press.

10. Hellberg C, Greene D, Boyes T (2007) Broadband Network Architectures: Designing and Deploying Triple-Play Services, Prentice Hall.

11. Parsons JJ, Oja D (2013) New Perspectives on Computer Concepts 2013: Comprehensive, Cengage Course Technology, $345 \mathrm{p}$. 12. Rosenau JN, Singh JP (2002) Information Technologies and Global Politics:
The Changing Scope of Power and Governance, State University of New York Press, $130 \mathrm{p}$.

13. Cherrayil NK, BYOD brings in plethora of network challenges', Gulf News (Abu Dhabi), 15 June 2013.

14. Fitzgerald B et al. (2011) Internet and E-Commerce Law: Technology, Law and Policy, Thomson Reuters Australia.

15. Copyright Act 1968 (Cth) s 10(1).

16. HH Sheikh Mansour Bin Zayed AI Nahyan, His Highness Sheikh Khalifa Bin Zayed Al Nahyan-The UAE President (17 August 2013) Khalifa Bin Zayed A Nahyan Foundation.

17. Aqil Kazim, The United Arab Emirates A.D. 600 to the present: A sociodiscursive transformation in the Arabian Gulf (Gulf Book Centre, 2000) 329; John
Anthony, Arab states of the lower gulf: People, politics, petroleum. (Middle East Anthony, Arab states of the lower gulf: People, politics, petroleum. (Middle East
Institute, 1975; Constitution of the United Arab Emirates (as amended 1996) Institute, 1975; Constitution of the United
(United Arab Emirates), 2 December 1971.

18. Young BJ (2005) Evaluating the Integration of Learning Technology at Zayed University, Doctoral Thesis, Griffith University, $5 \mathrm{p}$.

19. UAE National Media Council, UAE Interact (4 September) UAE Government.

20. Young BJ (2005) Evaluating the Integration of Learning Technology at Zayed University, Doctoral Thesis, Griffith University, 8p.

21. Glenn HP (2010) Legal Traditions of the World, (4th edition) Oxford University Press, pp184-187.

22. Palfrey J, Zittrain J, Deibert R, Rohozinski R (2008) Access Denied: The Practice and Policy of Global Internet Filtering, MIT Press, 406p.

23. Palfrey J, Zittrain J, Deibert R, Rohozinski R (2008) Access Denied: The Practice and Policy of Global Internet Filtering, MIT Press, 407p.

24. Palfrey J, Zittrain J, Deibert R, Rohozinski R (2008) Access Denied: The Practice and Policy of Global Internet Filtering, MIT Press, 408p.

Int J Journalism Mass Comm

ISSN: 2349-2635
25. BBC Online, United Arab Emirates will not ban Blackberries (8 October) BBC 26. On Combating Cybercrimes (United Arab Emirates) Federal Decree-Law no. (5) of 2012, Issued on 25 Ramadan 1433 AH Corresponding to 13 August 2012.

27. Cybercrime Law (United Arab Emirates) Federal Decree-Law No. (2) of 2006, Issued on Muharam $1427 \mathrm{AH}$ Corresponding to January 2006.

28. O'Connell N (2013) Developments in the UAE Cyber Crimes Law, 259 Al Tamimi Law Update 1.

29. Copyright and Related Rights (Neighboring Rights), IP Regulatory Body, Traditional Cultural Expressions, Utility Models (United Arab Emirates) Ministerial Decision No 411 of 1993 , Issued on 1 September 1993.

30. Dubai Technology, Electronic Commerce \& Media Free Zone Law (United Arab Emirates) Law No (1) of 2000, Issued 25 Shawwal 1420AH Corresponding to 31 January 2000.

31. Concerning Copyrights and Neighboring Rights (United Arab Emirates) Federal Law No. 7 of 2002, Issued on 1 July 2002.

32. Concerning the Formation and Protection of the Telecommunication Network for Dubai Internet City (United Arab Emirates\} Law No (6) of 2002, Issued on 10 November 2002

33. Electronic Transactions and Commerce Law (United Arab Emirates) Law No 2 of 2002, Issued on 30 Thi Al-Qedah 1422 Corresponding to 12 February 2002.

34. On Trademarks (United Arab Emirates) Federal Law No. (37) of 1992, amended by Law No 19 of 2000 and Law No 8 of 2002, Issued on 28 September 1992.

35. Regarding the Organization of the Telecommunications Sector (United Arab Emirates) Federal Decree-Law No. (3) of 2003, amended by Decree-Law No (5) of 2008, Issued 20 Ramadan 1424H Corresponding to 15 November 2003.

36. Amending the Dubai Technology, Electronic Commerce and Media Free Zone (United Arab Emirates) Law No 11 of 2004, Issued on 3 Ramadan 1425 Corresponding to 17 October 2004

37. On Collective Management of Copyright and Related Rights (United Arab Emirates) Ministerial Decision No 133 of 2004, Issued on 22 March 2004, Entry into force of original text 23 September 2011.

38. On Compulsory Licensing of Copies or Translations of Works (United Arab Emirates) Ministerial Decision No 134 of 2004, Issued 22 March 2004, Entry into force of original text 23 September 2011.

39. Concerning Consumer Protection (United Arab Emirates) Federal Law No 24 of 2006, Issued on 13 August 2006, and Entry into force of original text 23 September 2011

40. Cybercrime Law (United Arab Emirates) Federal Decree-Law No. (2) of 2006 Issued on Muharam 1427 AH Corresponding to January 2006.

41. Pertaining to the Industrial Regulation and Protection of Patents, Industrial Drawings, and Designs (United Arab Emirates) Federal Law No. 31of 2006, Issued on 24 July 2002.

42. Data Protection (United Arab Emirates) Data Protection Law No 1 of 2007 amended by Law No 5 of 2012, Issued December 2012.

43. Regarding the issuance of Certification Service Provider Regulations (United Arab Emirates) Ministerial Resolution No (1) of 2008, Issued 31 December 2008.

44.On The Establishment Of The National Electronic Security Authority (United Arab Emirates) Federal Decree-Law No. 3 of 2012, Issued on 25 Ramadan 1433 AH Corresponding to 13 August 2012.

45. On The Regulation Of Competition (United Arab Emirates) Federal Law No. 4 of 2012, Issued on 24 Dhu al-Qi'dah $1433 \mathrm{AH}$ corresponding to 10 October 2012.

46. On Combating Cybercrimes (United Arab Emirates) Federal Decree-Law no (5) of 2012, Issued on 25 Ramadan 1433 AH Corresponding to 13 August 2012.

47. Atkinson B (2007) The True History of Copyright: The Australian Experience 1905-2005, Sydney University Press.

48. Atkinson B (2007) The True History of Copyright: The Australian Experience 1905-2005, Sydney University Press, $1 \mathrm{p}$.

49. Atkinson B (2007) The True History of Copyright: The Australian Experience 1905-2005, Sydney University Press, 419p.

50. Fitzgerald B,Gamertsfelder L(1998) A Conceptual Framework For Protecting the Value of Informational Products through Unjust Enrichment Law. Australian Bar Review 16: 3.

51. House of Representatives: Standing Committee on Infrastructure and Communications, 'At what cost? IT pricing and the Australia tax' (Commonwealth of Australia, July 2013) 108; Copyright Act 1968 (Cth) s 10(1). 
Citation: Young BJ (2014) A Comparative Study of the Legal Frameworks and Protection of Digital Content in the United Arab Emirates and Australia in Relation to the Practice of Blocking Digital Content on the Basis of Location (Geo-Blocking) and its Associated Circumvention Technologies Int J Journalism Mass Communicat 1: 101. DOI: http://dx.doi.org/10.15344/2349-2635/2014/101

52. House of Representatives: Standing Committee on Infrastructure and Communications, 'At what cost? IT pricing and the Australia tax' (Commonwealth of Australia, July 2013) 108; Copyright Act 1968 (Cth), 115

53. House of Representatives: Standing Committee on Infrastructure and Communications, 'At what cost? IT pricing and the Australia tax' (Commonwealth of Australia, July 2013) 108; Copyright Act 1968 (Cth), xiii.

54. Competition and Consumer Act 2010 (Cth) (Australia) s 51(3).

55. House of Representatives: Standing Committee on Infrastructure and Communications, 'At what cost? IT pricing and the Australia tax' (Commonwealth of Australia, July 2013) 108; Copyright Act 1968 (Cth), 111.

56. House of Representatives: Standing Committee on Infrastructure and Communications, 'At what cost? IT pricing and the Australia tax' (Commonwealth of Australia, July 2013) 108; Copyright Act 1968 (Cth), 38.

57. Stevens v, Kabushiki Kaisha Sony Computer Entertainment (2005) 221 ALR 448.

58. House of Representatives: Standing Committee on Infrastructure and Communications, 'At what cost? IT pricing and the Australia tax' (Commonwealth of Australia, July 2013) 108; Copyright Act 1968 (Cth), 49.

59. House of Representatives: Standing Committee on Infrastructure and of Australia, July 2013) 108; Copyright Act 1968 (Cth), xii. 60. House of Representatives: Standing Committee on Infrastructure and
Communications, 'At what cost? IT pricing and the Australia tax' (Commonwealth Communications, 'At what cost? IT pricing and the Australia
of Australia, July 2013) 108; Copyright Act 1968 (Cth), xiii.

61. House of Representatives: Standing Committee on Infrastructure andCommunications, 'At what cost? IT pricing and the Australia tax' (Commonwealth of Australia, July 2013) 108; Copyright Act 1968 (Cth), 84.

62. House of Representatives: Standing Committee on Infrastructure and Communications, 'At what cost? IT pricing and the Australia tax' (Commonwealth of Australia, July 2013) 108; Copyright Act 1968 (Cth), xiii.

63. Digital Economy Act 2010 (UK) c 24, 124G(3).

64. Digital Economy Act 2010 (UK) s 17.

65. Digital Economy Act 2010 (UK) s 17(7)(a).

66. Copyright Legislation Amendment (Fair Go for Fair Use) Bill 2013 (Cth).

67. Australian Law Reform Commission, Copyright and the Digital EconomyALRC (2013) Australian Government.

68. Australian Law Reform Commission (2012) Copyright and the Digital Economy, Issue Paper No 42.

69. Australian Law Reform Commission, Copyright and the Digital Economy, Issue Paper No 42 (2012), 30.

70. Mendina T, Britz JJ (2004), Information Ethics in the Electronic Age: Current Issues in Africa and the World, McFarland,175p.

71. Flew T, Suzor N, Liu BR (2013) Copyrights and copyfights: copyright law and the digital economy. Int J Technology Policy and Law, 1: 3.

72. Roadshow Films Pty Ltd v iiNet Limited (No. 3) [2010] FCA 24.

73. Larrikin Music Publishing Pty Ltd v EMI Songs Australia Pty Ltd (2010) [2010] FCA 29.

74. Telstra Corporation Ltd v Phone Directories Company Pty Ltd [2010] FCA 44.

75. Copyright Amendment (Digital Agenda) Act 2000 (Cth) s 112E.

76. University of New South Wales $v$ Moorhouse And Angus \& Robertson (Publishers)Pty Ltd (1975) 6 ALR 193.

77. Paltiel M (2013) Navigating cyberspace-Australian precedent regarding internet liability, 16(2) Internet Law Bulletins 26.

78. Roadshow Films Pty Ltd v iiNet Ltd [2012] HCA 16.

79. Singtel Optus Pty Ltd v National Rugby League Investments Pty Ltd (No 2) [2012] FCA 34.

80. Hinchliffe S (2012) Time for change? Up and away ... storage in a cloud or feet on the ground?, 25(5) Australian Intellectual Property Law Bulletin

81. Hinchliffe S (2012) Time for a review of automated programmes and free-toair services: National Rugby League Investments Pty Ltd v Singtel Optus Pty Ltd FCAFC 59' (2012) 25(1) Australian Intellectual Property Law Bulletin 2.

82. Vitoria M (2011) Laddie, Prescott and Vitoria: The Modern Law of Copyright and Designs (4th edition) LexisNexis, 913.
83. Court Suppression and Non-Publication Orders Act 2010 (NSW) s 6

84. Fairfax Digital Australia and New Zealand Pty Ltd and Others v Ibrahim and others (2012) 293 ALR 384.

85. Rinehart v Welker [2011] NSWCA 403

86. Seet S, Aplin W (2013) Phonographic Performance Co of Australia Ltd v Commercial Radio Australia Ltd,296 ALR 607.

87. Gasser U (2006) Research Publication No. 2006-04: Legal Frameworks and Technological Protection of Digital Content: Moving Forward Towards a Best Practice Model, Harvard Law School: The Berkman Center for Internet \& Society.

88. Gasser U (2006) Research Publication No. 2006-04: Legal Frameworks and Technological Protection of Digital Content: Moving Forward Towards a Bes Practice Model, Harvard Law School: The Berkman Center for Internet \& Society, 21

89. Gasser U (2006) Research Publication No. 2006-04: Legal Frameworks and Technological Protection of Digital Content: Moving Forward Towards a Best Practice Model, Harvard Law School: The Berkman Centerfor Internet \& Society, 42.

90. Gasser U (2006) Research Publication No. 2006-04: Legal Frameworks and Technological Protection of Digital Content: Moving Forward Towards a Best Practice Model, Harvard Law School: The Berkman Center for Internet \& Society, 9

91. Singtel Optus Pty Ltd v National Rugby League Investments Pty Ltd (No 2) [2012] FCA 34.

92. Ricketson S, Ginsburg J (2006) International Copyright and Neighbouring Rights: The Berne Convention and Beyond (2nd edition) Oxford University Press; Berne Convention for the Protection of Literary and Artistic Works (Berne Convention), opened for signature 9 September 1886, WO001EN (entered into force 5 December 1887)

93. U.S. v Elcom Ltd., 203 F.Supp.2d 1111 (N.D.Cal., 2002).

94. Digital Millennium Copyright Act (DMCA), 112 Stat. 2860 (1998).

95. Australia-United States Free Trade Agreement, Australia-United States, signed 18 May 2004, FTA (entered into force 1 January 2005).

96. WIPO Performances and Phonograms Treaty (WPPT), opened for signature 20December 1996, WO033EN (entered into force 20 May 2002).

97. Copyright Amendment (Digital Agenda) Act 2000 (Cth) (Australia).

98. Copyright Amendment (Digital Agenda) Act 2000 (Cth) (Australia) s 4, 5

99. House of Representatives: Standing Committee on Legal and Constitutional Affairs, 'Review of technological protection measures exceptions' (Commonwealth of Australia, February 2006).

100. Gasser U (2006) Research Publication No. 2006-04: Legal Frameworks and Technological Protection of Digital Content: Moving Forward Towards a Best Practice Model, Harvard Law School: The Berkman Centerfor Internet \& Society, 13.

101. Harpur PD, Suzor N(2013) Copyright Protections and Disability Rights: Turning the Page to a New International Paradigm. University of New South Wales Law Journal 36: 3 .

102. Strauss A, Corbin JM (2008) Basics of Qualitative Research: Techniques and Procedures for Developing Grounded Theory, (2nd edition) Sage Publications.

103. Glaser GB, Strauss AL (1979) The discovery of grounded theory: Strategies for qualitative research, Transaction Publishers.

104. Seidel S, Urquhart C (2013) On emergence and forcing in information systems grounded theory studies: the case of Strauss and Corbin. $J$ Inform Technol 28: 237-260.

105. Charmaz K (2006) Constructing Grounded Theory: A Practical Guide through Qualitative Analysis SAGE Publications Ltd, $224 \mathrm{p}$.

106. Omar A, Hamid D, Alias N, IslamMd (2010) Grounded Theory: A Short Cut to Highlight a Researchers' Intellectuality (2010) J Social Sci 6: 276-281.

107. Lynne Connelly, above $\mathrm{n} 105$.

108. Hoecke MV (2011) Methodologies of Legal Research: Which Kind of Method for What Kind of Discipline, Hart Publishing.

109. Glaser GB, Strauss AL (1979) The discovery of grounded theory: Strategies for qualitative research, Transaction Publishers, 103p.

110. StraussA, Corbin J (1990) Basics of qualitative research: Grounded theory procedures and techniques, Sage Publication LTD, 116.

111. Guba EG, Lincoln YS (1989) Fourth generation evaluation, SAGE Publications, Inc, 213p

112. Delice A (2010) The Sampling Issues in Quantitative Research. Educational Sciences Theory \& Practice 10: 2001-2018.
Int J Journalism Mass Comm

ISSN: 2349-2635
IJJMC, an open access journal Volume 1. 2014. 101 
Citation: Young BJ (2014) A Comparative Study of the Legal Frameworks and Protection of Digital Content in the United Arab Emirates and Australia in Relation to the Practice of Blocking Digital Content on the Basis of Location (Geo-Blocking) and its Associated Circumvention Technologies Int J Journalism Mass Communicat 1: 101. DOI: http://dx.doi.org/10.15344/2349-2635/2014/101

Page 11 of 11

113. Convention on Cybercrime (Budapest Convention on Cybercrime), opened for signature 23 November 2001, CETS No. 185 (entered into force 1 July 2004).

114. World Intellectual Property Organization (WIPO) Copyright Treaty (WCT) opened for signature 20 December 1996, WO033EN (entered into force 6 March 2002; WIPO Performances and Phonograms Treaty (WPPT), opened for signature 20 December 1996, WO033EN (entered into force 20 May 2002)

115. Bazeley, Jackson K (2013) Qualitative data analysis with NVivo,(2nd edition) SAGE Publications Ltd, $328 \mathrm{p}$.

116. Statement of Mr. Samuel L. Clemens, Arguments Before The Committees On Patents of the Senate and House of Representatives, On The Bills S. 6330 and H.R. 19853, To Amend and Consolidate the Acts Respecting Copyright, December 7-11, 1906

117. Murray A (2002) Ficsor: The Law of Copyright and the Internet: The 1996 Wipo Treaties, Their Interpretation and Implementation, Oxford University Press, $10 \mathrm{p}$.

118. Tom Mendina and Johannes J. Britz, above $\mathrm{n} 71,177$

119. Gasser U (2006) Research Publication No. 2006-04: Legal Frameworks and Technological Protection of Digital Content: Moving Forward Towards a Best Practice Model, Harvard Law School: The Berkman Centerfor Internet \& Society, 41.

120. Gasser U (2006) Research Publication No. 2006-04: Legal Frameworks and Technological Protection of Digital Content: Moving Forward Towards a Best Practice Model, Harvard Law School: The Berkman Centerfor Internet \& Society, 46.

121. Gasser U (2006) Research Publication No. 2006-04: Legal Frameworks and Technological Protection of Digital Content: Moving Forward Towards a Best Practice Model, Harvard Law School:The Berkman Centerfor Internet \& Society, 47.

122. Gasser U (2006) Research Publication No. 2006-04: Legal Frameworks and Technological Protection of Digital Content: Moving Forward Towards a Best Practice Model, Harvard Law School: The Berkman Center for Internet\& Society, 48.

123. Stevens's $v$ Kabushiki Kaisha Sony Computer Entertainment and Others (2005) 221 ALR 448, 489.

124. Interactive Games and Entertainment Association, Submission No 14 to Senate Standing Committees on Environment and Communications, Copyright Legislation Amendment (Fair Go for Fair Use) Bill 2013, 30 August 2013.

125. Australia-United States Free Trade Agreement, Australia-United States, signed 18 May 2004, FTA (entered into force 1 January 2005).

126. Interactive Games and Entertainment Association, Submission No 14 to Senate Standing Committees on Environment and Communications, Copyright Legislation Amendment (Fair Go for Fair Use) Bill 2013, 30 August 2013, 4.

127. Interactive Games and Entertainment Association, Submission No 14 to Senate Standing Committees on Environment and Communications, Copyright Legislation Amendment (Fair Go for Fair Use) Bill 2013, 30 August 2013, 6 .

128. Australian Recording Industry Association (ARIA), Submission No 15 to Senate Standing Committees on Environment and Communications, Copyrigh Legislation Amendment (Fair Go for Fair Use) Bill 2013, 30 August 2013.

129. Australian Law Reform Commission, Copyright and the Digital Economy, Issue Paper No 42 (2012), 30.

130. Gasser U (2006) Research Publication No. 2006-04: Legal Frameworks and Technological Protection of Digital Content: Moving Forward Towards a Best Practice Model, Harvard Law School: The Berkman Center for Internet \& Society, 41.

131. Convention on Cybercrime (Budapest Convention on Cybercrime), opened for signature 23 November 2001, CETS No. 185 (entered into force 1 July 2004).

132. Maurushat A (2011) Australia's Accession to the Cybercrime Convention: Is the Convention Still Relevant in Combating Cybercrime in the Era of Botnets Is the Convention Still Relevant in Combating Cybercrime in the Era of Botnets
and Obfuscation Crime Tools?. University of New South Wales Law Journal 33: and Obfusce
$431-473$.

133. John Hilvert, Could geo-blocking be deemed anti- competitive? (26 March) itnews for Australian Business.

134. Hilvert J, Could geo-blocking be deemed anti- competitive? (26 March) itnews for Australian Business

135. Suzor N (2004) Privacy v IP Litigation: preliminary third party discovery on the Internet. Australian Bar Review 25: 228.

136.Privacy Amendment (Enhancing Privacy Protection) Act 2012 (Cth) sch 1 $\mathrm{cl} 8$.

137. Kalinich K (2013) Data sovereignty and the cloud-a lawyer's guide: legal and risk governance issues around data hosting and jurisdiction. Internet Law Bulletin.
138. On Issuance of The Penal Code (United Arab Emirates) Federal Law No (3) of 1987, Issued on 16 Raby` al-THaany 1408A.H. Corresponding to 8December 1987

139. On Issuance of The Penal Code (United Arab Emirates) Federal Law No (3) of 1987 , Issued on 16 Raby` al-THaany 1408 A.H. Corresponding to 8 December 1987 , art 378

140. O' Connell N (2013) Legal Issues in Cloud Computing-Part, 2013(1) Law Update 1.

141. On Issuance of The Penal Code (United Arab Emirates) Federal Law No (3) of 1987 , Issued on 16 Raby` al-THaany 1408 A.H. Corresponding to 8 December 1987 art 158.

142. Suzor N (22 July 2013) Statements from: The beginning of the end for geoblocking?, Business Spectator.

143. Lohman T, Geoblocking in Australia to be dismantled (29 July) ZDNET.

144. Mott WT ((1975) The Rhetoric of Martin Luther King, Jr.: Letter from Birmingham Jail. Phylon 36:417.

145. Black J, Roberts C (2011)Doing Ethics in Media: Theories and Practical Applications, Taylor \& Francis, $456 \mathrm{p}$.

146. Gasser U (2006) Research Publication No. 2006-04: Legal Frameworks and Technological Protection of Digital Content: Moving Forward Towards a Best Practice Model, Harvard Law School: The Berkman Center for Internet \& Society, 8.

147. Paine A (1935), Mark Twain's Notebook: Journal Entries 1865-1908, Harper \& Brothers, From Chapter 33 - Back in America, 381p. 